\title{
Crime Story in the Macedonian Printed Daily Newspapers
}

\author{
Stefanovska Vesna*
}

Faculty of Security-Skopje, University “Kliment Ohridski” - Bitola, Republic of Macedonia

\begin{abstract}
The paper examines the media coverage of crime in the Macedonian printed newspapers and the way in which certain circumstances related to the offender, the victim and the crime are depicted. The content analysis is based on quantitative and qualitative data collected from the media articles within three-month period by using written coding instrument.

The main findings indicate that there are different approaches to and prioritization of criminal offences worth publishing in daily newspapers. The latter exhibit uneven representation of violent compared to property crimes, which means that the former crimes compared to property felonies, although less frequent in occurrence, note higher representation in part of the newspapers. In addition, differences according to the place of crimes commission are noticed between media in Macedonian and Albanian. Albanian media tend to emphasize crime perpetrated in areas where majority population is of Albanian origin compared to other major municipalities in the country. In this way, one gets the impression that these areas are incomparably much more burdened with crime, which makes them less safe than other major municipalities.

The findings relate only to media texts published in the printed newspapers on the research topic and to the classifications and definitions contained in criminal laws. Therefore, in-depth analysis on crime news depiction, not only in printed media, but also in electronic media in general, and at the web portals, in particular is challenging for scholars. This will bring new scientific insight into Macedonian criminological critical thoughts related to the role and meaning of the media and their discourse in construction of crime and criminality.
\end{abstract}

Keywords: Crime story, crime news, daily newspapers, media, presentation.

\section{INTRODUCTION}

The media, as means of communication are part of our everyday lives. We cannot image that the society could function without mass communication through the media. In conditions of social mobility, channel expansion, and open competition among the media, we can often meet the attitude that the objectivity in the media is illusory (Turkewitz, R. Ripley 2010: 214). They, based on a pluralistic model for ideological war, represent a forum for debate, and consciously or unconsciously, they use or abuse the possibility to manipulate with the truth or the untruth, with the facts and interpretations (Jewkes 2004: 29). For this reason, Jewkes (2004) ascertains that during the examination of the stories in the media, reversed questions are being asked. Not about what media do for people, but what people do with the media in an era of democratic and interactive communications led by the technology (Jewkes 2004: 28).

Considering the fact that there are several types of mass media, each type has its own features, and rules on how to present the events, all these types, more or less, have their own distinct features that are subject of a special debate among the professionals and the public.

*Address correspondence to this author at the Faculty of Security-Skopje, University "Kliment Ohridski" - Bitola, Republic of Macedonia; Tel: 00389022546211; Fax: 00389022545070; E-mail: vstefanovska77@gmail.com
Within the framework of the print media, the daily newspapers have a special place. Due to their informative and politic character and the function to inform about the daily news in the area of politics, culture, economy, society, as well as about the attitudes, the scientific community more frequently analyzes opinions and comments regarding current events, this type of media.

Featuring the daily news, the topic of crime is a common and a crucial part of the daily newspapers and depending on many elements of the criminal event; it can be on the front page, on the popular political section, on the economic section or on the black chronic page. As a result, we arise following questions: whether the crime news are a reflection of the reality not only regarding the crime figures in the country, but also regarding the specific criminal event described and depicted in the newspaper, what is the role and importance of the media in regard to crime presentation. In sum, how can we explain the connection between crime and media?

For the first question, the comparison between the portrayed and real crime is an indicator for the objectivity in the presentation of the crime according to both the rate and types. Furthermore, the selection of criminal offences, which offences are followed in their further criminal proceeding and which crime situations are analyzed in more details depends on many factors. The editorial policy of the media and the certain criteria and values that should be taken into consideration in 
order to publish the story (to be newsworthy for publishing) is most notable.

Because, based on many research data, the selection process creates distorted image of the real crime figures, we raise the questions about the extent of that distortion not only quantitatively, but also qualitatively (in terms of the manner in which the crime is portrayed in the media). In addition, main subject of interest is the contribution and influence of the media on the social institutions regarding the crime and criminal problems.

One thing is clear. Media, with the help of the crime news, support, reform or make the most dominant crime definitions. In this way, they have the power to design the public perception of the crime, in a manner that is true or distorted. In that context, the media and politicians often assign conventional and cultural meaning to those who break the law. By doing that, they reject the possibility to present another, alternative or opposite explanation about the crime, criminal behavior, and the criminal law (Jewkes 2004: 141). Chamberlain (2013) properly elaborates this in his publication: Understanding Criminological Research. He states that certain discourse practices and sources (those launched by the media) introduce certain subject-positions and social identities, while at the same time close, marginalize or silence others (Chamberlain 2013: 142). This means that the media can increase the deviance of certain categories of offenders and offences, and, at the same time, can camouflage, or even exclude the deviance of other negative behaviors. In that regards, the selection of the crime news and the manner in which they are portrayed have an influence on the individual attitudes and perceptions about the crime. The crime stories affect, shape, or alter our attitude about the crime. They cause a fear sensation, insecurity, panic, feelings, stimulate the stigmatization, and can increase condemnatory attitude, stereotypes, intolerance, and demands for harsher penal policies. Nils Christy (2003) shares the similar opinion, and according to him, in the modern capitalist society, the information about the crime offered by the media is increasing and in that way people rely on the media when they describe and give importance to what happens, including the crime (Stefanovska 2014).

\section{Some Research Results}

Bearing in mind the previous stated, the research results indicate that the media has the power to create categories, offences, and offenders and to determine the limits and definitions for deviations and crime. For example, the discourse used to describe certain criminal activities has an influence on the social construction of these criminal activities, as well as on the public discourse used to describe them. In that sense, very interesting to analyze is the manner in which the authors frame and shape the story, because, how they produce the text is one thing, but how the audience interpret that text is completely another thing. In that context, the authors and readers are subject of discourse practices that influence and are influenced by the dominant social and cultural norms. Therefore, it is very important how the social and cultural matrix in which the author writes and produces effects the selection of certain expressions and stories, which are shaping the texts (Oenbring 2011: 54). On the other hand, the readers as consumers with different level of knowledge and different perspectives interpret the words and storied based on their feelings for identity, their experience, and family and social relations ets.

The thesis that the content of the text has an impact on its interpretation by causing shock or calling for revenge is true, and it serves to mobilize the readers' response and reaction. According to Katz, J. (1987: 70 ), the crime news are classified as hot news that stimulate readers to react against the insecurity. Turkewitz (2013) believes that the newspapers standardize the stories and lose the complexity of the current news (Turkewitz, R. Ripley 2010: 3). They narrow the public narratives, which limits the public perception and understanding of crime. According to Dowler the stories are created in accordance to certain frame that supports the dominant governmental structure and promotes gender, race, sexuality and class stereotypes. In fact, these stories are becoming stereotypes that help readers to interpret "stereotypically" their experiences.

For example, regarding the rape cases, Dowler considers that the media use a framework, which helps the selection of the cases and the discussions about them. The authors shape the stories based on already existing narratives about rape as a criminal offence and describe the victims, also based on previously existing definitions about the rape victims. This type of story simplification helps the community to easily absorb and understand it (Turkewitz, R. Ripley 2010: 11).

Mayers (1997), concerning the portrayed domestic violence, says that the crime news expand the idea and thesis that the violence is a result of an individual 
psychopathology, i.e. it is a case of isolated pathology or deviance. Therefore, the media do not relate domestic violence to the social roots that refer to both, the patriarchy and the control over the women (Adampa 1999: 22). Similarly, Jewkes (2004) argues that the crime in media is portrayed because of an individual pathology, and the crime among powerful people is ignored or misrepresented. Regarding the offenders, Greg Barak (2004) considers that the label, stereotypes and criminalization of certain groups, mostly based on class, gender and race are still present (Jewkes 2004: 26).

Regarding the traits of the victim and the offender, the media frequently develop profiles of ideal offenders and ideal victims. Depending on the offence, the offenders are psychopaths, violent, businesspersons or professionals, while victims are labeled as passive, defenseless, and fragile (Dowler 2003). Alheide (2007) speaks that the media create legitimate victims, which covers children, women, old and defenseless citizens, while other victims, such as drug addicts, the homeless and sexual workers, according to the discourse that presents them, more difficulty gain a status of legitimate victims in the eyes of the public. Hereinafter, considering the language and style used in describing the crime victims, there is a danger in the media of creating hierarchy regarding the victimization scale. In fact, there is a danger of certain marginalized groups to be less covered than other victims that would lead to the conclusion that the ones are more important than the others are. For example, the homosexuals and the spouses as homicide victims are minimally covered, compared to the foreigners who are over-presented in the media. This manner of selective presentation creates distorted image about the victims, in which certain categories are more visible compared to other categories (Dowler 2003). During the analysis of the presented victims and offenders in several studies, Reiner (2007) recognized that in the media, older offenders of higher social and economic status are more covered, compared to the traits of the offenders registered in the official statistics. Similar data are obtained about the victims too. In the media, the victims are usually older women of higher social status, mostly from the white race, while according to the official data, they are poor, young Afro-American mothers (Reiner 2007). The above-mentioned data show us that with the selective presentation of the offenders and victims, the media unrealistically rank and stereotype both parties of the criminal event.
The research about the criminal offences committed by "wall street" and the Latino immigrants in USA also supports the fact that the race, and the social and economic status of the victims and offenders have a big influence on how crime news are presented. The victims are positively portrayed and the negative influence and consequences caused by the white-collar crimes are minimized. On the other hand, the crime committed by the Latino immigrants is negatively portrayed and it has a negative influence on the perception of the Latino community that increases the demand for harsher immigration policy (Catalano and Waugh 2013: 407).

Furthermore, regarding the manner in which offences were committed, the research show that criminal offences, which occur rarely and in an unusual manner, are more frequently covered by the media, because it causes emotional reactions and shock among readers. In spite of this, these criminal offences can be present in the media for days and weeks, which increase their deviance, condemnation and wish for revenge (Alheide L. David 2003: 17).

The previous findings and dilemmas, due to the presumed influence over the individual attitudes and perceptions, provoke my research pursuit to analyze media coverage of the crime in printed newspapers.

\section{NOTES ON METHODOLOGY}

Subject of research is the actual crime in the Republic of Macedonia, which is covered by the media in three daily printed newspapers (Dnenvik, Vest and Koha) in the period between $10^{\text {th }}$ November 2014 and $10^{\text {th }}$ February 2015.

The selection of the above-mentioned newspapers was made based on the national coverage, popularity, circulation, and length of existence.

Dnevnik is the first privately held printed newspaper in the Republic of Macedonia that started with publishing in March 1996 (the first edition was published in March 20, 1996) and it is the most circulated newspaper in Macedonia, with an average circulation of 55.000. Regarding the current political beliefs, it leans toward the dominant political authority.

Vest is also a popular printed newspaper with longstanding existence (the first edition was published in June 7,2000$)$. The editorial policy was permanent till the end of 2015, and according to their political 
observations, the newspaper was considered as neutral, or more critically determined to the political party in power.

Koha is a daily newspaper published in Albanian by 2009 and therefore has limited readership, but has national coverage and is widely accepted by the Albanian community in Macedonia.

Within three month period 401 media texts are collected related to the committed crimes, out of which 135 texts are published in Vest, 155 are published in Dnevnik and 111 texts in Koha.

Certain phenomenological features of media reported crime have been analyzed as part of the survey: scope, type, place, time and manner of perpetration, certain socio-demographic characteristics of offender and victim and some other circumstances related to criminal event like motive, consequences, etc. In this context, the focus has been placed on the link between the type of the criminal offence and other elements presented in the article. They refer to the following issues: is the offender known to law enforcement authorities, is there data on offender's and victim's sex, age and ethnic background, is the criminal offence committed by one or more persons, the place of the crime commission, is the offender national or foreign citizen, what is the relation with the victim and other features of offenders, was the criminal offence committed by use of violence, i.e. by use of cold steel or fire-arms, etc.

The analysis of different aspects of media reported crimes in the three daily newspapers placed particular focus on differences and similarities in crime presentation and media discourse used.

The purposes of the survey are as follows. 1. to find out the way in which the media understand the crime and the way in which they communicates such perception to the public, what reflection of crime they make using different sources of evidence, how they define the crime and what definitions of crime do they present to reader; 2 . to find out whether media coverage of crime corresponds with the type and the scope of the crime recorded in the official records of law enforcement authorities, 3. to realize whether there are differences in crime reporting in different daily newspapers depending on editing policy or 4 . whether there are processes of stereotyping, stigmatization, favoring or prejudice towards certain groups and categories of persons related to criminality.
To data analyze we have applied quantitative and qualitative content analysis and for data coding, a coding instrument was applied.

\section{RESULTS AND DISCUSSION}

\section{Circumstances Related to the Crime, the Offender and the Victim}

\section{State of Reported Crime}

The crimes in the daily newspapers are divided into nine categories. Those are: violent crime (all acts that include violence body injury, aggravated bodily injury, participation in a brawl, threatening with a dangerous instrument, exposure to danger, coercion, unlawful arrest, kidnapping, preventing an official person performing an official act etc.), 2. murder (including attempt to murder), 3. sexual crime (all crimes against sexual freedom and sexual morality (rape, sexual attack upon a child, incest, statutory rape of a helpless person, mediation in conducting prostitution, showing pornographic materials to a child, statutory rape with misuse of position), 4. property crime (theft, severe theft, robbery и armed robbery), 5. Drug related crimes, 6. smuggling migrants, 7. smuggling other goods, 8 . White-collar crime (crimes against official duty, i.e. crimes committed with abuse of the official duty, misconducting in the service, defraud in the service etc.) and 9. other (others crimes which do not belong in the previous groups).

Criminal offences against property always make the biggest portion of the overall crime. In Dnevnik, the most represented crimes include thefts, aggravated thefts, and robberies (25\%). Violent crimes are second ranked $(18.45 \%)$, followed by crimes of illegal drugs trafficking (10.1\%). Compared to Dnevnik, the most represented crimes in Vest are the violent crimes (33.3\%). Crimes against property hold second position and white-collar crimes are the third ranked criminal offences. In Koha, violence involving crimes are the first ranked, crimes against property second and crimes of illegal trade in drugs are the third ranked.

With regard to violent crimes offences, data on murders as the most severe crimes is sorted out and they get special media space in daily newspapers. Vest published 44 articles on other violent crimes, which constitutes $1 / 3$ of the overall reported crime. Among those, the highest portion concerns body assaults (68.2\% or 30 cases). $40 \%$ of the body assaults happen between young people or groups of students, equally high portion happens between adults, while $15 \%$ of the 
Table 1: State of Certain Types of Crime Reported in the Printed Newspapers in the Republic of Macedonia

\begin{tabular}{|c|c|c|c|c|c|c|}
\hline & Dnevnik & $\%$ & Vest & $\%$ & Koha & $\%$ \\
\hline Murder (attempt to murder) & 8 & 4,8 & 9 & 6,4 & 7 & 6,1 \\
\hline $\begin{array}{l}\text { Violent crime } \\
\text { Family violence } \\
\text { Physical attacks and serious threats against police }\end{array}$ & $\begin{array}{c}31 \\
4 \\
7\end{array}$ & 18,5 & $\begin{array}{c}47 \\
10 \\
5\end{array}$ & $\begin{array}{c}33,3 \\
21,0 \\
11\end{array}$ & $\begin{array}{c}30 \\
8 \\
4\end{array}$ & $\begin{array}{c}26,1 \\
30 \\
15,4\end{array}$ \\
\hline Sexual crime & 5 & 3,0 & 8 & 5,7 & 6 & 5,2 \\
\hline Property crime & 42 & 25,0 & 20 & 14,2 & 28 & 24,3 \\
\hline Illegal trafficking with drugs & 17 & 10,1 & 11 & 7,8 & 12 & 10,4 \\
\hline Illegal trafficking with arms & 7 & 4,2 & 4 & 2,8 & 2 & 1,7 \\
\hline Smuggling immigrants & 15 & 9,0 & 11 & $\begin{array}{l}7,8 \\
2,8\end{array}$ & 6 & 5,2 \\
\hline Smuggling other goods & 11 & 6,5 & 4 & 2,8 & 1 & 0,9 \\
\hline White-collar crime & 14 & 8,3 & 14 & 9,9 & 5 & 4,3 \\
\hline other & 25 & 14,9 & 17 & 12,1 & 20 & 17,4 \\
\hline Total & $168^{1}$ & 100,0 & 141 & 100,0 & 115 & 100,0 \\
\hline
\end{tabular}

body assaults (five cases) are commissioned upon police officers.

Less than $1 / 4$ of the crimes (10 cases) are related to family violence, five of which concern family violence or body assault against wives (in seven cases) or intimate partner (in two cases), while other cases concern threats and violence of children upon parents, mostly due to certain drugs or alcohol addictions. Only in one case, physical fight occurred between brothers. Other violence involving criminal offences include verbal threats, vandalism, or explosive setting in public areas. This representation indicates that Vest allocates equal media space to violence among young people, family violence and body assaults upon citizens.

Dnevnik allocates the largest media space to body assaults, too. Around $70 \%$ of the articles report on participation in a brawl, that is physical fights, most of which occur between young people. Compared to Vest, Dnevnik places stronger accent on body assaults upon police officers.

With reference to family violence, analysis of the articles leads to the conclusion that Dnevnik reports double less on criminal offences committed within family. During the survey period, four cases were reported (compared to 10 in Vest), two of which

${ }^{1}$ In certain media articles, more than one crime is published. Therefore, the number of actual crimes is bigger than the number of media articles related to actual crimes concerned family violence (compared to seven in Vest). These figures reflect the low interest in informing the public of this phenomenon, or marginalization of women as vulnerable category of victims while highlighting police officers as victims of body assault.

The ratio between victims of family violence and police victims in Vest is 2:1, while in Dnevnik it is 1:2. This confirms that both phenomena are present in reality, the difference being that media reality in Vest reflects family violence while Dnevnik focuses on police victimization.

\section{Profile of the Offender}

Analysis of certain characteristics of the offender by sex, age, ethnic background, profession, and citizenship has produced the following results:

\section{Known and Identified Offender}

The portion of known offenders in the articles in Vest, Dnevnik and Koha ranges within similar scales from $75.7 \%$ in Koha, 77.8 in Dnevnik to 78.1 in Vest. According to the type of criminal offence, data indicates that high percentage of violent and property crimes are with unknown offender at the time of the crime dissemination. This raises questions like: Is dissemination of criminal offences prior to disclosure of their offenders aimed at warning the public that robberies and thefts are frequent events and does rapid leaving of the event scene without disclosure and identification of the offenders lessen the chances of 
their revealing and capturing by law enforcement authorities later? The set assumption corresponds with the police efficiency rate, ranging around $25 \%$ for thefts with declining trend, which indicates that offenders are more and more becoming professionals and commit the crime in a manner that reduces the possibility for their revealing and capturing by the law enforcement authorities.

Similar situation occurs with violent crimes (body assaults) where identification of the offender is easier in later proceedings due to immediate contact with the victim. Nonetheless, the fact that offenders are unknown to police immediately after the criminal offence and after its reveal, (more than 1/3 of violent crimes are with unknown offender) leaves certain messages to the public. That assaults and endangering of safety (these crimes comprise criminal offences of explosive devices, destruction of other's vehicle, writing of offensive words) by unknown offenders increase the feeling of fear and uncertainty even more.

Although the identity of the persons suspected to have committed a crime has to be protected as they are protected by the fundamental right to a presumption of innocence, low percentage of known offenders is identified (around 10\% of articles). This means that media, wishing to reinforce the deviation for different motives and reasons, infringe the basic procedural law in relation to certain offenders and criminal offences. For example, disclosure of the names of the perpetrators of murders committed in three cities supplemented by photographs of their faces exposes to the public the guilty and the murderer who should be thus punished both publicly and legally. Additional message sent in this way is that their doing should not be forgotten which fosters the feeling of rage and revenge towards offenders.

In the case of disclosure of the names of inspectors who did not take the gun off the perpetrator of triple murder in Kavadarci, media personalized the responsibility for that case in order to "silence" further accusations against police at higher organizational level.

Disclosure of the identity of certain officials who have misused their official duty (current mayor, former mayor, and former official) and underlining of their public position leaves behind several messages. 1. Impairment of their public reputation, 2. leaves obligation to follow court proceedings thus making latent pressure on judiciary, 3. Confirmation of doubts with part of the public that authority is corruptive, but the legal system of the Republic of Macedonia functions well, and 4. Disclosure of the names of the offenders is an example for and warning to other public officials that their wrongdoings will not remain unrevealed and unpunished.

Comparing the daily newspapers, the highest percentage of identified offenders is reported in Vest $(12.3 \%)$, in Koha (9.6\%) and the lowest one in Dnevnik $(8.2 \%)$.

\section{Sex of the Offender}

The sex of the offender in explosive setting in public areas in Vest is identified in $67.8 \%$ of the cases, $74.7 \%$ being offenders of male sex, $2.1 \%$ female (three out of 141 criminal events concerning illegal stay, misuse of official duty and blackmail) and in seven cases (4.8\%) offenders are of male and female sex. In Dnevnik, sex of the offenders is identified in $71.3 \%$ of the cases and offenders are males in $77.3 \%$ of the cases and females in $5.3 \%$ (in Dnevnik, sex is identified in seven offences involving perpetration of the criminal offences smuggling of other goods, property felonies and fraud). In 6 of the cases, offenders are of male and female sex. Sex of the offenders in Koha is identified in $71.3 \%$ of the cases with $68.7 \%$ being offenders of male sex.

The above-mentioned indicators suggest the following. First, in Dnevnik, female crime is presented as property crime and women as able and ready to commit fraud and smuggle certain goods. Second, considering the high number of violations involving illegal stay disseminated in Koha, and having in mind that the persons in question are foreign female citizens, we may conclude that our country enables illegal stay or that there is demand for female workforce in certain parts of Macedonia. Consequently, the conclusion would be that either foreign female citizens are not able to find jobs in their domicile countries (including mostly Kosovo, Albania and Bulgaria) or they are offered better working conditions in Macedonia, especially in the Tetovo-Gostivar area of the country. And, third, representation of female offenders in Vest is lower because Vest, compared with Dnevnik and Koha reports less on crimes against property, smuggling other goods and illegal stay and those are the most frequent criminal offences perpetrated by female persons in the survey period. 


\section{Ethnic Background and Citizenship of the Offenders}

Ethnic background in Vest is identified in $17.8 \%$ of the cases most often along with identification of citizenship considering that $5.5 \%$ of the cases stress that offenders are foreign citizens, while offenders are both Macedonian and foreign citizens in $15.8 \%$ of the cases. Articles mention Albanian ethnic background (in five cases) and Greeks (in three cases), Turks, Germans, Polands (one case of each during the survey period). Foreign citizens are most often perpetrators of the following criminal offences: smuggling or trafficking of foreign exchange (three cases recorded), smuggling of migrants, drug trafficking, bribe, and family violence in one case. In Dnevnik, ethnic background together with the citizenship of the offender is identified in $22.8 \%$ of the cases, among which domicile citizens occur in $8.8 \%$ of the cases. Foreign citizens originate most often from Albania and Greece, but citizens from Poland, Germany, Russia, America, Montenegro, Bulgaria, and Serbia are identified as well. They are most often perpetrators of the following criminal offences: trafficking of foreign exchange or cigarets (in five cases), drug trafficking (in four cases), migrants smuggling (in four cases), falsification of official documents (in two cases), violence (in three cases), robbery and aggravated theft (in one case) and illegal stay (one case). In Koha, ethnic background is identified in $17.4 \%$. The offender is foreign citizen in $11.4 \%$ of the cases, domicile citizen in $73.7 \%$, while domicile and foreign citizens together are registered in $8.8 \%$ of the cases. Compared to other newspapers, Albanian ethnic background is highlighted in the highest number of articles (seven) regardless of whether it refers to a foreign citizen, and Serbian ethnic background is mentioned in five cases. We also encounter offenders from Kosovo, Poland and Germany. Foreign female citizens, as mentioned earlier, are most often perpetrators of the criminal offence "illegal stay" and "lack of working permit" (in nine cases) and one isolated case of theft, migrants smuggling, drug trafficking and trafficking of foreign exchange.

The above indicates that cases of criminal offences perpetrated by foreign citizens on the territory of the Republic of Macedonia are not rare. Considering the fact that high number of those is revealed on border crossings, the subject criminal offences concern trafficking of foreign exchange or other goods, smuggling of migrants and illegal drug trafficking.

\section{Age of the Offender}

With regard to the age of the offender, $61.0 \%$ of the cases in Vest involve adult offenders, $6.8 \%$ children and $30.8 \%$ of the cases involve offenders whose age cannot be determined mostly because offenders are unknown. Children are most often perpetrators of violent criminal offences (in six cases). Besides those, the following offences are recorded: a case of theft, rape, drug trafficking and migrants smuggling. This data indicates that juvenile crime reported during the survey period is characterized with violence. In Dnevnik, offenders are adults in $67.3 \%$ of the cases, while in $7 \%$ of the cases they are children and cannot be determined in $24 \%$ of the articles. In Dnevnik, children are most often perpetrators of violent criminal offences (in five cases) and property felonies (in four cases). In Koha, $62.6 \%$ of the offenders are adults, $7 \%$ children and age of the offenders cannot be determined in $27.8 \%$ of the cases.

\section{Offender's Profession}

Offender's profession is identified in around $20 \%$ of the articles. In Vest, six of the cases reveal police profession, while managerial positions in certain public offices (Director of the State Environmental Inspectorate, Mayor, Director of Labour Inspection) and civil servants in certain public services (treasurer, municipal employees, personnel of the administration for legal property affairs) are stated in eight cases. Owners of private companies are indicated in three cases and the following are mentioned from among other professions: medical doctor, waiter, musicians, dancers, journalists, and khoja. In Dnevnik, profession is identified in $19.9 \%$ of the cases and police profession is highlighted again (in six cases) where police officers are perpetrators of the following criminal offences: bribe in two cases, causing general danger, migrants smuggling and negligent performance of duty. In addition, managing positions of offenders having misused their position to commit certain criminal offences are stated: mayor (in two cases), president of association, director of agency for radiation activity, clergyman, and director of labour inspection. In Koha, profession is identified in $21.7 \%$ of the cases.

In general, the analysis of data leads to the conclusion that offenders' profession is identified where the crime is committed by misuse of official position to point out the service in question or while performing their professions as dancers, farmers, clergy leaders, musicians, professional solders, etc. Indication of the profession is actually additional description of the criminal offence and highlighting that crime occurs in 
public offices by their officers and holders of high-level positions. Furthermore, data indicates that crime committed by civil servants is more journalists' target than the one committed by private professions.

With regard to other features of the offenders, they are recidivists or formerly convicted offenders or they committed the crime under the influence of alcohol. In certain situations, offenders are identified as pickpockets (for three criminal offences of pocket theft), robbers, thieves, dealers, illegal diggers, paedophiles, vagrant, mentally disordered, attackers and bullies.

The mentioned attributes show that in some cases media use stereotype terms (dealers), dramatic terms (robbers) or terms accepted in vocational literature though reflecting pathological side of the person (paedophile, vagrant, pickpocket).

\section{Circumstances Related to Criminal Offences}

\section{Individual and Group Crime Commission}

According to the number of offenders, the rates of group and group commission of crimes is similar in the three newspapers. Around $50 \%$ of the criminal offences are committed by a single offender, $35 \%$ to $38 \%$ are committed by two and more offenders and the rest of the cases lack specific data on this aspect. With regard to violent crimes, it is interesting to note that around $65 \%$ of the criminal offences in Vest are committed by more than one offenders. If we exempt offences of family violence, which are most often committed by a single offender, then it turns out that attacks by several persons, compared with attacks by a single person, are almost double. Group violence in Dnevnik and Koha is represented with 40 to $45 \%$.

Property felonies are characterized by being committed by more than one offenders $(60 \%$ in Vest, $57.5 \%$ in Koha and $52.4 \%$ in Dnevnik).

\section{Place of Crime Commission}

The place of the crime commissioning is indicated in most of the cases. In Vest, it is stated in $82.9 \%$ of the cases, in Dnevnik and in Koha in high $93 \%$ and $93.9 \%$ of the cases, respectively.

Data obtained shows that the highest portion of perpetrated crimes reported in Dnevnik and Vest are recorded in Skopje and Skopje region (30\% of the criminal offences), while Koha reports more on criminal offences commissioned in Tetovo and Tetovo region where majority of the population is of Albanian ethnic affiliation (28\%). The second position in Dnevnik is held by criminal offences commissioned on border crossings (29\% of the offences) (mostly offences of goods smuggling, migrants smuggling and drug trafficking), which confirms the conclusion that the said criminal offences account for high proportion of the overall reported crime. Crimes commissioned in Tetovo and Tetovo region (10\%) are the third ranked in Dnevnik. Opposite situation has been observed in Vest, i.e. criminal offences commissioned in Tetovo region (16\%) hold second position, while the third one is occupied by offences commissioned on border crossings and in Ohrid Municipality (8\%).

In Koha, data indicates that criminal offences recorded in Skopje are reported as second ranked $(23 \%)$, criminal offences recorded in Gostivar and Gostivar region are reported as third ranked (10.3\%), which is double and triple compared to criminal offences reported in Vest and Dnevnik, respectively.

Taking into account that, according to the crime trends, based on data of the Sectors for internal affairs $(S I A)^{2}$, the ratio of criminal offences recorded by SIA Skopje and other SIA's is approximately 7:1, 8:1 etc., which indicates that the number of recorded criminal offences in Skopje is seven times higher than the overall number of criminal offences recorded in Tetovo, Bitola, Kumanovo and Ohrid. This data indicates that daily newspapers communicate unproportional representation of offences by the place of commission, especially in Kumanovo, Bitola and Ohrid regions where the rate of commission is similar to the number of offences commissioned in Tetovo - Gostivar region.

In contrast with the official statistics of the Ministry of Interior (MI), the ratio between criminal offences commissioned in Skopje and Tetovo-Gostivar region is 2.3:1 in Dnevnik, 1.5:1 in Vest and 1:1.5 in Koha. For the crimes in Kumanovo region, the ratio is $11: 1$ in Dnevnik, 8:1 in Vest and 7:1 in Koha. The ratio of crimes commissioned in Bitola and Ohrid regions is similar.

Based on data presented above, we may conclude that media tend to stress and report crime commissioned in areas where the majority of the population is of Albanian ethnic origin compared to

\footnotetext{
${ }^{2}$ According to the data released on the web site of the Ministry of interior, registered crimes according to sectors for internal affairs for 2013 are as follows: 16.434 crimes registered in SIA Skopje, 2.369 crimes registered in SIA -Bitola, 2.285 crimes in SIA -Kumanovo, 2.260 crimes in SIA - Tetovo and 2.051 crimes in SIA - Ohrid. Those data indicate that crimes registered in SIA Tetovo are at fourth place compared to the others sectors. available at: http://62.162.77.57/DesktopDefault.aspx?tabindex=0\&tabid $=614$
} 
other major municipalities in the country. Furthermore, the analysis of data leaves the impression that these areas are much more burdened with crime, which makes them less safe compared to other major municipalities (Kumanovo, Bitola, Ohrid). Predominance of criminal offences reported from Tetovo-Gostivar region in Koha relative to Skopje and other municipalities also indicates that the newspaper covers more the areas populated with Albanian population. Consequently, the higher rate of crime commission compared to other municipalities raises augmented feeling of unsafety among local population.

\section{Manner and Means of Criminal Offence Commissioning}

Violence is involved in around $50 \%$ of the reported criminal offences and data presented is in line with the representation of the type of offences in daily newspapers. With regard to the use of fire arms and cold steel, data indicates that $30 \%$ and more than 30 $\%$ of the overall number of criminal offences are perpetrated with certain instrument.

\section{Characteristics of Victim}

Prior to the analysis of victim's characteristics, we should answer the question of the portion of reported offences having immediate victim. In doing so, the immediate victim within the meaning of this report means direct victims of criminal offences including victims of thefts (burgling) and robberies (which are not always personalized in media articles) and having suffered body or psychological injuries or economic loss. The overall number of victims does not include migrants owing primarily to the impossibility to ascertain the number of smuggled migrants within the registered offences.

In the context of the above, immediate victim in offences reported in Vest is recorded in $61.4 \%$ of the cases, in Koha in $58.3 \%$, and in Dnevnik in less than half of the cases (in $48.2 \%$ ). Such proportional differences between the three newspapers are expected considering that Vest and Koha report more of violent crimes which always involve immediate victim, while Dnevnik covers more the offences of migrants smuggling, goods smuggling and offences of drug trafficking where no immediate physical victims are recorded.

\section{Identity, Sex and Age of Victims}

With regard to disclosure of victim's identity, data presented confirm that it is disclosed in media for certain cases, although in small percentage which is similar in the three newspapers. In the surveyed newspapers, the identity is disclosed for criminal offences of murder and where the victim holds certain public position (Member of Parliament, judge). In exceptional cases dealing with specific criminal offences (theft of vaginas from sexy-shops) or in isolated cases, the identity of damaged party is disclosed. The sex in Vest is identified in most of the cases $(74.2 \%)$, among which the sex is male in $58.9 \%$ of the cases and male in $15.6 \%$. Based on reported information, women are due to their vulnerability most often victims of violence, including family violence, as well as verbal threats or threats endangering their safety. Also, in most of the cases of sexual abuse, victims are persons of female sex, but there are also persons of male sex in this role. On the other side, the sex of the victim in Dnevnik is identified in $66.7 \%$, among whom $24.7 \%$ are females. Compared to Vest, in Dnevnik, besides the mentioned forms of crime, five cases of robbery against girls working in shops and markets are also reported and their sex is revealed in the newspaper.

In Koha, the sex is identified in $71.2 \%$ of the cases, $51.6 \%$ of which are of male sex, $26.6 \%$ of female sex, and $14.1 \%$ both male and female, while in $7.8 \%$ of the cases it cannot be determined. Female persons are more frequently victims of violent crime, most of which to family violence and there are attacks and threats upon female clerks during their official tasks performance. In addition, victims of female sex occur among robberies and given the fact that those offences are most often perpetrated in shops, pharmacies, betting shops and alike, they can become target of attack as employees. One case of rape and one case of blackmail upon female juvenile person are reported.

With regard to victim's age, children are most frequently victims of sexual and violent crimes and theft in lower number of cases. Thus, whereas certain offences are reported simultaneously in all newspapers, in more than half of the sexual assaults (rape, unallowed sexual acts, unauthorized recording of pornographic material), offences are commissioned upon children, while body assaults and other violent offences are reported in five cases in Vest and in seven cases in Dnevnik and Koha.

The above presented data indicates that cases of sexual assault upon children reported in media are frequent which sets the alarm of the severity of this phenomenon. Owing to such representation in media, 
the public is usually mobilized in demanding stricter sanctioning policy towards perpetrators of these criminal offences especially where victims are children.

\section{Profession and Number of Victims}

With reference to victim's profession in media texts, we can make a rough division by the form of offences commissioned and by the frequency of their victims. Thus, 1. victims of robberies include most frequently employees in betting shops, petrol stations, shops and migrants; 2. victims of body assaults by identified profession are police officers; 3 . victims of thefts are owners of salons and 4. victims of serious threats and endangering their security are holders of certain public positions (female Member of Parliament, judge, inspectors in certain inspection authorities of the state administration).

The above presented data generates perception in the public that publicly accessible job positions and jobs involving work with money are more risky compared to other professions. Data also testifies that police officers are often objects of attacks and this communicates the impression to the public of the augmented risk of police service.

With regard to the issue whether the offence involves one or more victims, data indicates that criminal offences with two or more victims are in most cases reported in Vest (38.9\% of the cases), then in Koha $(37.9 \%)$ and the least in Dnevnik $(28.4 \%)$. This data is in line with the type of criminal offences as Vest and Koha, opposite to cases reported in Dnevnik, report more on violent offences, which in high portion involve more than one victims. So, violent crimes are most frequently commissioned upon more than one victims and this ratio with property felonies is approximately 2:1 in Vest and Koha, while the ratio in Dnevnik, due to higher number of reported robberies and thefts, is almost 1:1. In addition, in the three newspapers, part of the reported crimes against sexual freedom and sexual morality is committed against more than one victim.

\section{Relationship between Offender and Victim}

In response to the question whether offender and victim know each other, data indicates that they know each other in nearly $1 / 3$ of the crimes involving victims, or in $37.8 \%$ in Vest, $30.3 \%$ in Koha and in the lowest percentage (23.8 \%) in Dnevnik. Among those, the highest percentage in Vest involves family relation (11.1 \% of all crimes involving victim), $3.3 \%$ are relatives while the term 'other' usually refers to former boyfriend and girlfriend (in five cases), neighbours (four cases), schoolmates, employee and employer in two cases and employee in school and female students in one case. In Dnevnik, as a result of the low number of cases of family violence reported, this percentage is the lowest $(2.7 \%)$, but it is higher for criminal offences perpetrated between relatives $(5.4 \%)$. Situation in Koha is similar with the one in Vest, which is reflected by the following data: in $11.5 \%$ of the crimes, offender and victim are in family relationship, $3.3 \%$ are relatives and $1.6 \%$ involves friendship.

The above data indicates that criminal offences are often commissioned between persons with misbalance in power, which assumes that the offender abuses his position of power for the crime perpetration.

\section{CONCLUSIONS}

There are different approaches to and prioritization of criminal offences worth publishing in daily newspapers. The latter exhibit uneven representation of violent compared to property crimes, which means that the former crimes compared to property felonies, although less frequent in occurrence, note higher representation in part of the newspapers. Besides this, there are different approaches to and prioritizing of the selection of offences from among the group of violent crimes in Vest and Dnevnik. Vest underlines more family violence and women as vulnerable category of victims, while Dnevnik places stronger emphasis on police officers as victims of body assaults. In this way, media generate hierarchy of victims as they give priority to some over others and communicate such priority to the audience, too. Therefore, the dilemma family violence or police as victim depends on the choice and rating of the newspaper. Furthermore, as more than $1 / 3$ of the violent crimes are with unknown offender, the public gets a message that assaults and endangerments of safety by unknown persons exist and augment the feeling of fear and uncertainty even more.

Contrary to other types of crime, the interest in reporting offences involving illegal drug trafficking and migrants smuggling is significant. This indicates that not only their scale is increased, but also the activities of the police are targeted at that crime detecting and revealing in media through press releases to public or other means of communication.

So, Vest notes higher rate of presenting articles involving violent elements: more violent crime, murders and sexual crime, while Dnevnik represents more 
offences related to drugs, migrants smuggling, other goods smuggling, property felonies and obstructing police officers in the performance of their official duties. Hence, by the object of assault, Dnevnik gives priority to property, illegal activities and attacks upon police authorities, while Vest to life, body and sexual freedom and morality.

Identity of offenders is disclosed for murders and certain officials who have misused their official position, which violates their fundamental right to presumption of innocence. The message in the former case is that perpetrators of murders cannot be hidden from the public eyes, by which they are stigmatized consciously and penalized additionally by citizens. In the latter case, doubts of part of the public that power is corruptive are affirmed, but the message is that the legal system in the Republic of Macedonia is operational and dissemination of the names of offenders is an example and warning to other public officials that their wrongdoings will not remain undisclosed and un-penalized. In both cases, by revealing the identity of offenders and assumed "duty" to follow court proceedings, both media and citizens make latent pressure on judiciary.

There are different approaches to and prioritizing of criminal events for publishing between media in Macedonian and Albanian according to the place of crimes commission. Albanian media tend to emphasize crime perpetrated in areas where majority population is of Albanian origin compared to other major municipalities in the country. In this way, one gets the impression that these areas are incomparably much more burdened with crime, which makes them less safe than other major municipalities. This style of reporting could be construed as two-edged weapon. This means that, on one side, Koha wishes to inform the inhabitants of Tetovo - Gostivar region of the status of crime in these areas, but due to uneven reporting, it generates perception that the rate of crime in their community is the highest.

Finally, according to the genre of the article, crime news are usually short news using the common conventional frame of information obtained from police sources which are in most cases the only sources of evidence. Besides answers to the basic issues related to criminal offence (who, where, how and why), journalists do not address reasons and other circumstances of relevance for the criminal event. This conclusion is affirmed by the fact that journalists covering and addressing this matter lack criminological knowledge and information and therefore only communicate the dominant definitions and views of the crime and thus shape the public opinion of it, too.

\section{REFERENCES}

Adampa, V. 1999. "Reporting of a violent crime in three newspaper articles. The representation of the female victim and the male offender and their actions: a critical news analysis", Working paper N0. 108, Centre for language in social life, Lancaster University, Department of Linguistics and Modern English Language, Retrieved October 17, 2014 (http://www. lancaster.ac.uk/fass/groups/clsl/pubs/clsl108.pdf)

Alheide L. David. 2003. Mass Media, crime and the discourse of fear, Hedgehog Review 5 (3): 9- 25.

Chamberlain, J. Martin. 2013. Understanding criminological research, SAGE publication.

Catalano, T. and Waugh, L. 2013. The ideologies behind newspaper crime reports of Latinos and Wall street / CEOS: A critical analysis of metonymy in text and image, in Critical discourse studies: $406-426$.

http://dx.doi.org/10.1080/17405904.2013.813774

Dowler, K. 2003. "Media consumption and public attitude toward crime and justice: the relationship between fear of crime, punitive attitudes, and perceived police effectiveness", Journal of criminal justice and popular culture, 10 (2): 109 126.

Jewkes, Y. 2004. Media and crime (first edition), SAGE Publication.

Katz, J. 1987. "What makes crime news?", Media, culture and society, SAGE Publication: 46 - 75.

Oenbring, R. 2011. "Framing Violence: A Content/Discourse Analysis of representations of violence in Bahamian Newspapers", Paper presented at Violence symposium $3^{\text {rd }}$ November, 2011, retrieved November 5, 2014 (http://ufdc.ufl.edu/ AA00012389/00001)

Reiner, R. 2007. "Media made criminality: the representation of crime in the mass media", The Oxford Handbook of Criminology edited by Maguire, M, Morgan, $\mathrm{R}$ and Reiner, Robert, Oxford University Press, Oxford, UK: $302-337$.

Stefanovska, V. 2014. "Constitutive criminology: Product of postmodern society", Proceedings of the International scientific conference Macedonia and the Balkans, a hundred years after world war, Faculty of security-Skopje: $398-409$.

Turkewitz, R. Ripley. 2010. "All the news that fits to print? A content analysis of newspapers' Portrayal of rape and sexual assault", Psychology Commons, Digital Commons Network, Social and Behavioral Sciences, Retrieved January 10, 2015 http://network.bepress.com/explore/social-and-behavioralsciences/psychology/?facet=subject_facet\%3A\%22Rape\%22

\section{DOI: http://dx.doi.org/10.6000/1929-4409.2016.05.02}

(c) 2016 Stefanovska Vesna; Licensee Lifescience Global.

This is an open access article licensed under the terms of the Creative Commons Attribution Non-Commercial License (http://creativecommons.org/licenses/by-nc/3.0/) which permits unrestricted, non-commercial use, distribution and reproduction in any medium, provided the work is properly cited. 